\title{
Effect of Industrial Waste on Strength Properties of Concrete
}

\author{
Bode Venkata Kavyateja ${ }^{1}$, Panga Narasimha Reddy ${ }^{2 *}$ \\ ${ }^{1}$ JNTUA College of Engineering, Kalikiri, Andhra Pradesh 517234, India \\ ${ }^{2}$ National Institute of Technology, Srinagar, Jammu and Kashmir 190006, India
}

Corresponding Author Email: narasimha_07phd16@nitsri.ac.in

https://doi.org/10.18280/acsm.440508

Received: 20 December 2019

Accepted: 18 August 2020

\section{Keywords:}

metakaolin, illuminate sludge, glass bottle, eco-friendly concrete, cement replacement

\begin{abstract}
Industrial wastes generally pumped into water bodies and soil that would pollute the atmosphere. As a control measure, industrial wastes products utilized as waste building materials. In the present research, waste products from various industries like illuminate sludge and glass bottle powder used in different dosages as a replacement for fine aggregate and metakaolin used as a cement replacement. Split tensile strength and compressive strength of the concrete samples examined for M30 grade. Fine aggregate is substituted by glass bottle powder (i.e. 10 to $40 \%$ ) and illuminate sludge (i.e. 10 to $30 \%$ ). Metakaolin substituted for cement replacement (i.e. 4 to $12 \%$ ). Glass bottle does not pollute the atmosphere, but the disposal of waste glass results wastage of land. Thereby glass bottle powder can be utilized as a cement replacement in the construction industry. Then the metakaolin and illuminate sludge are the waste products from the titanium product. The experiment performed to assess the strength properties by incorporating various industrial wastes in different dosages. Physical tests of all three products have carried out according to the code requirements. Three specimens have been tested for each industrial waste products ratio to examine the tensile and compressive strength of concrete at 7th day, 14th day and 28th day and eventually to cure to achieve the optimum strength of concrete. Addition of these industrial wastes into the concrete showed an outstanding improvement in modulus of rupture, split tensile strength and compressive strength at an early and later ages.
\end{abstract}

\section{INTRODUCTION}

There are so many forms and quantities of waste produced by various manufacturing industries. These waste products from different sectors will pollute the water, soil and air sources, and eventually end up in the sea. Industrial waste disposal is one of the critical components of the industrial waste management system. Groundwater and land are heavily contaminated by industrial waste and effluents. Many of our waste sources highly contaminated by industrial waste and also affect those people who consume this water. The dumping of industrial waste in the sea also allows it to be unfit for the survival of marine life.

In the current research, illuminate sludge and glass bottle powder incorporated as a fine aggregate replacement, and metakaolin utilized as a cement replacement. This study concerned with the substitution of waste products for various components with different dosages in the concrete to achieve an enhancement in the strength properties of the concrete than reference mix and also with the reduction of environmental pollution.

Anwar [1] investigated properties of M40 grade of concrete with binder substitution by $5 \%, 10 \%$ and $15 \%$ to $50 \%$ by mass. The optimum strength observed with $10 \%$ substitution, and that would enhance modulus of rupture by $7 \%$, tensile strength by $8 \%$ and compressive strength by $17 \%$. Glass powder incorporated into concrete as a cement and fine aggregate replacement by Shayan [2]. Glass powder particles ranging from less than $10 \mu, 4.75 \mathrm{~mm}$ to $0.15 \mathrm{~mm}$ and $12 \mathrm{~mm}$ to
$4.75 \mathrm{~mm}$ utilized as cement, fine and coarse aggregate, respectively. According to his report, fine and coarse aggregate replaced by $50 \%$ and cement replacement by $30 \%$ glass powder in concrete with an acceptable range of strength [3-9]. Dinakar et al. showed that $10 \%$ substitution of metakaolin gives the maximum split tensile strength and compressive strength to produce high performance and high strength concrete [10]. Replacement of cement with 5\%, 10\%, $15 \%$ and $20 \%$ metakaolin reported by Dr. Felixkala and Narmatha [11]. From their research, increased metakaolin quantity enhanced tensile and compressive strength by up to $15 \%$ cement substitution [11]. According to Ligoria and Balakrishnan, cupola slag used for fine as well as coarse aggregate replacement with $15 \%$ on M25 and M20 grade of concrete, the results showed maximum compressive strength [12].

Therefore, in this study, the effect of illuminate sludge and glass bottle powder as fine aggregate substitution and metakaolin as cement replacement on strength properties of concrete will be investigated.

\section{MATERIALS}

\subsection{Cement}

53 grades of ordinary Portland cement have been used in the current research. Cement is usually glue or binding agent of the concrete, which not only binds all the various concrete 
components together but also give strength to the concrete. Table 1 shows the physical properties of cement.

Table 1. Physical properties of cement

\begin{tabular}{cc}
\hline Parameter & Obtained results \\
\hline Final setting time & 350 minutes \\
Initial setting time & 148 minutes \\
Specific gravity & 3.13 \\
Fineness of cement & $4.35 \%$ \\
Consistency & $30 \%$ \\
\hline
\end{tabular}

\subsection{Coarse aggregate}

Crushed granite was used as coarse aggregate in this study. The coarse aggregate was free from impurities. The maximum size of the coarse aggregate was $12 \mathrm{~mm}$, and its specific gravity is 2.64 and satisfying the BIS $383-1970$ requirements [13]. Physical properties of coarse aggregate are shown in Table 2.

Table 2. Physical properties of coarse aggregate

\begin{tabular}{cc}
\hline Parameters & Obtained Results \\
\hline Water absorption & $0.49 \%$ \\
Specific Gravity & 2.68 \\
Fineness modulus & 2.59 \\
Impact & 30 \\
\hline
\end{tabular}

\subsection{Fine aggregate}

In the present research, river sand utilized as fine aggregate and it should be free from organic matter, hard and clean for the better-quality concrete mix. Table 3 shows the physical characteristics of fine aggregate.

Table 3. Physical characteristics of fine aggregate

\begin{tabular}{cc}
\hline Parameter & Obtained results \\
\hline Specific gravity & 2.7 \\
Fineness modulus & 2.8 \\
\hline
\end{tabular}

\subsection{Water}

Water is essential for the hydration process in the cement concrete. Topwater is used for the production of concrete and $\mathrm{pH}$ value of the water is observed to be 6.9 that indicate the water is free from the organic matters.

\subsection{Glass bottles}

Waste glass bottle from the beverage industry has been obtained from the roadside. Glass bottles are cleaned and crushed into small size comparable to zone II sand grading after drying. Crushed particles sieved with the help of IS sieve of size $4.75 \mathrm{~mm}$ and $150 \mu$ is used for this research. Physical characteristics of glass bottles powder are shown in Table 4. Physical appearance of glass bottle powder is shown in Figure 1.

Table 4. Physical characteristics of waste glass bottle powder

\begin{tabular}{cc}
\hline Parameter & Value \\
\hline Fineness modulus & 3.4 \\
Specific gravity & 3.7 \\
\hline
\end{tabular}

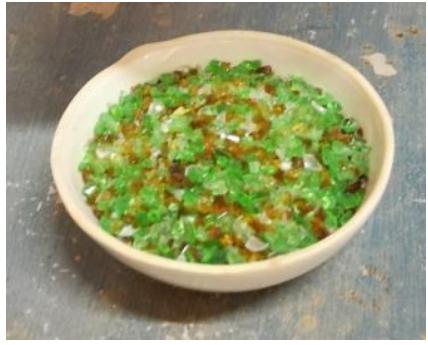

Figure 1. Glass Bottle powder

\subsection{Metakaolin}

Metakaolin is one of the materials which is Pozzolanic in nature. It can be used as a cement substitution in the production of concrete. The metakaolin of size less than $75 \mu$ is used in the current research. The physical properties and appearance of metakaolin are shown in Table 5 and Figure 2, respectively.

Table 5. Physical properties of metakaolin

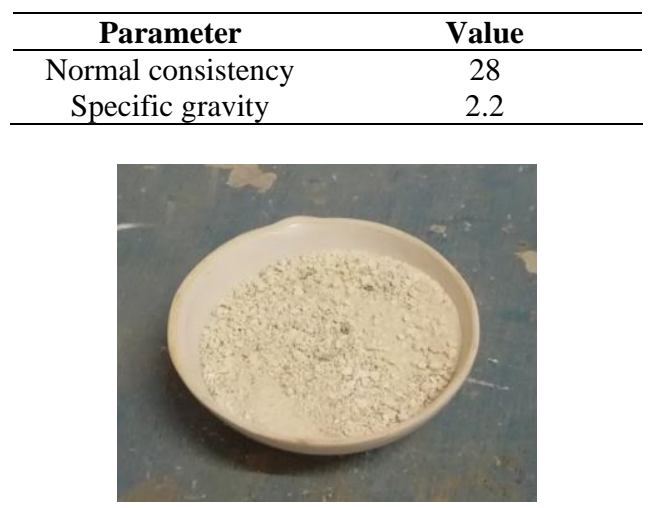

Figure 2. Metakaolin

\subsection{Illuminate sludge}

Illuminate sludge is a by-product in the production of titanium dioxide. Illuminate sludge is dried under the sunlight. It has been sieved through IS sieve of the size of $75 \mu$. Physical appearance and characteristics of illuminate sludge are shown in Figure 3 and Table 6, respectively.

Table 6. Physical properties of Illuminate sludge

\begin{tabular}{cc}
\hline Parameter & Obtained results \\
\hline$\%$ Bulking & $12 \%$ \\
Water absorption & $24 \%$ \\
Initial setting time & 140 minutes \\
Fineness modulus & 3.01 \\
Normal consistency & 31 \\
Specific gravity & 4.1 \\
\hline
\end{tabular}

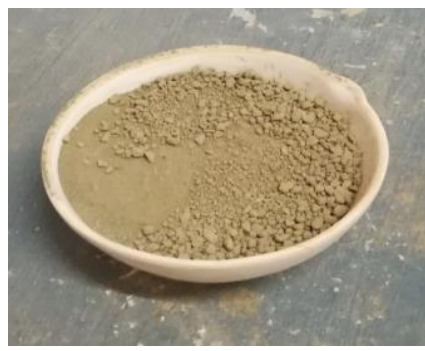

Figure 3. Illuminate sludge powder 


\section{METHODOLOGY}

Materials are expected to be gathered and checked as recommended by The IS. Fineness modulus, water absorption, impact and specific gravity tests have been carried out in coarse and fine aggregate according to IS 2386-1963 [14] and obtained test values are within the permissible limits. Physical properties tests on cement-like final and initial setting time, fineness, specific gravity and consistency have been performed as per IS: 4031 - 1988. Illuminate sludge and glass bottle powder was incorporated to concrete by partially substituting fine aggregate in $10 \%, 20 \%, 30 \%$ and $10 \%, 20 \%$, $30 \%, 40 \%$, respectively. Cement is partially replaced by metakaolin with a dosage of $4 \%, 8 \%$ and $12 \%$. Tensile strength and compressive strength of concrete specimens have been tested at 7th, 14th and 28th day to know the variation in strength parameters incorporating industrial waste products.

\section{MIX PROPORTION}

A concrete mix of M30 grade (1:1.9:34) with 0.45 water to cement ratio has been designed according to the IS 456-200 [15] and IS 10262-1982 specifications [16].

\section{FABRICATION OF CONCRETE SPECIMENS}

For the right mixing, adequate monitoring has been performed. The compressive strength test has been performed on cube samples of size $150 \mathrm{~mm}$ and cylindrical samples of size $300 \mathrm{~mm}$ long and $150 \mathrm{~mm}$ diameter was used to assess the tensile strength of concrete. Twenty-four hours is reserved for the setting of concrete in the mould in a levelled surface. After 24 hours, concrete samples are shifted from steel mould to curing tank for 7 days, 14 days and 28 days.

\section{TESTING}

Cylindrical and cube samples were tested to examine tensile strength and compressive strength, respectively. Tensile strength and compressive strength have been performed on compression testing machine of $3000 \mathrm{kN}$ capacity with a rate of loading $2.5 \mathrm{kN} / \mathrm{s}$ was adopted which is nearly equivalent to $140 \mathrm{~kg} / \mathrm{cm}^{2} /$ minutes as stated in IS: $516-1959$ [17].

\section{RESULTS AND DISCUSSION}

\subsection{Compressive strength}

Compressive strength (CS) of concrete was improved with adding of glass bottle powder, illuminate sludge and metakaolin up to $30 \%$ replacement to fine aggregate, $10 \%$ replacement with cement, $8 \%$ replacement with cement, respectively.

Figure 4, the strength enhancement with $30 \%$ glass replacement by $22.496 \%, 22.465 \%$ and $22.515 \%$ at 7,14 and 28 days, respectively. The compressive strength was improved with $10 \%$ replacement illuminate sludge with cement by $9.6542 \%, 9.632 \%$ and $9.668 \%$ at 7,14 and 28 days, respectively, as shown in Figure 5. From Figure 6, the strength enhancement was observed at $8 \%$ replacement of cement with metakaolin by $78.625 \%, 78.589 \%$ and $78.61 \%$ at 7,14 and 28 days, respectively. The strength enhancement was more with metakaolin in concrete compared to illuminate sludge and glass bottle powder at 7,14 and 28 days for M30 grade of concrete. The CS of concrete was increased by filling of micropores with metakaolin, glass bottle powder and illuminate sludge powder at an early and later age [18-20].

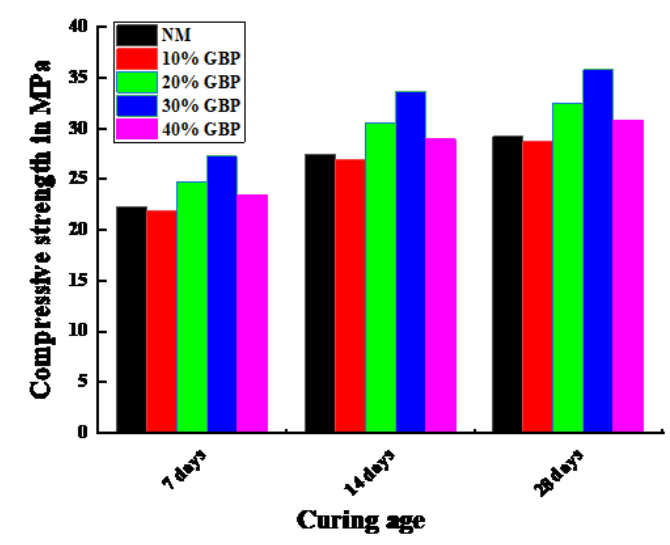

Figure 4. CS of concrete with \% glass replacements

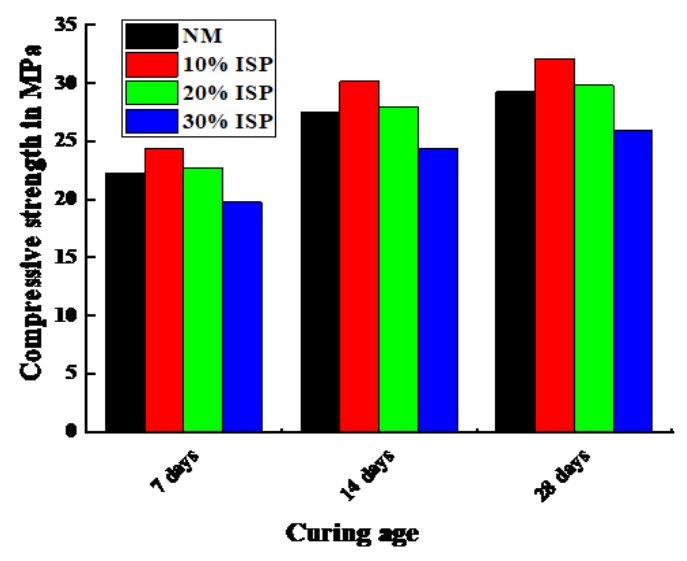

Figure 5. CS of concrete with \% illuminate sludge powder

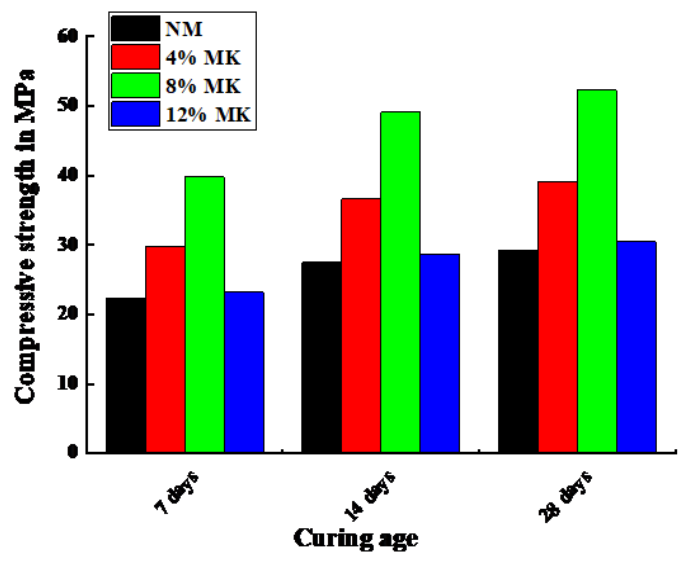

Figure 6. CS of concrete with \% metakaolin replacement

\subsection{Split tensile strength}

Split tensile strength of concrete was increased with adding of glass bottle powder, illuminate sludge and metakaolin up to $20 \%$ replacement to fine aggregate, $10 \%$ replacement with cement, $8 \%$ replacement with cement, respectively. From Figure 7 , the strength enhancement with $20 \%$ glass replacement by $84.78 \%, 54.11 \%$ and $51.93 \%$ at 7,14 and 28 
days, respectively. The compressive strength was improved with $10 \%$ replacement illuminate sludge with cement by $65.94 \%, 66.40 \%$ and $66.29 \%$ at 7,14 and 28 days, respectively, as shown in Figure 8. From Figure 9, the strength enhancement was observed at $8 \%$ replacement of cement with metakaolin by $166.66 \%, 167.05 \%$ and $167.40 \%$ at 7,14 and 28 days, respectively. The strength enhancement was more with metakaolin in concrete compared to illuminate sludge and glass bottle powder at 7,14 and 28 days for M30 grade of concrete. The split tensile strength of concrete was enhanced due to improvement of inter transition zone with the addition of metakaolin, glass bottle powder and illuminate sludge powder at an early and later age [21-25].

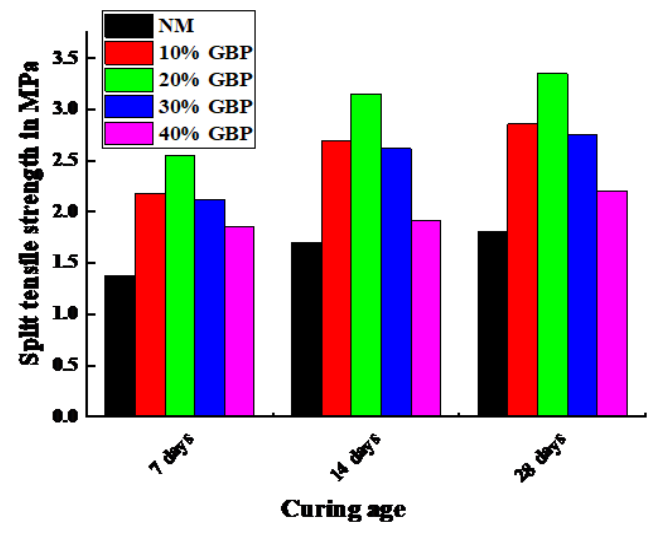

Figure 7. Graphical representation of SPS of concrete with $\%$ glass bottle powder

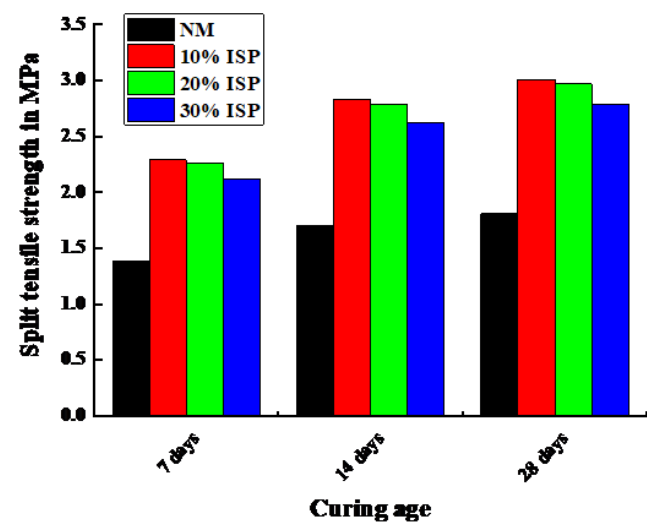

Figure 8. Graphical representation of SPS of concrete with $\%$ illuminate sludge powder

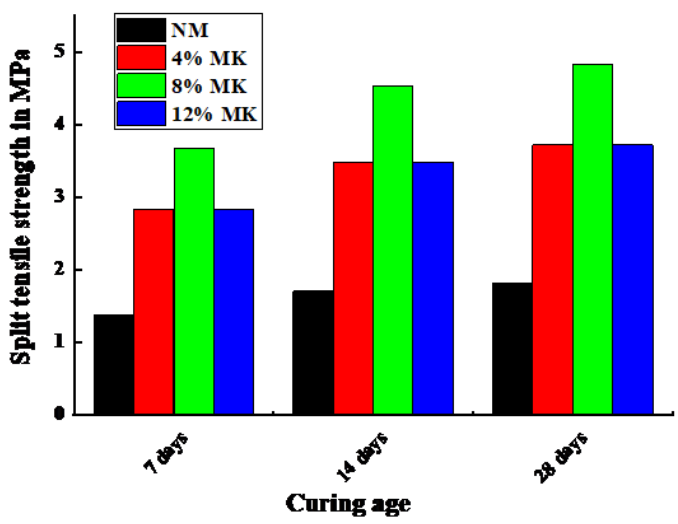

Figure 9. Graphical representation of SPS of concrete with $\%$ metakaolin powder
7.3 Modulus of rupture

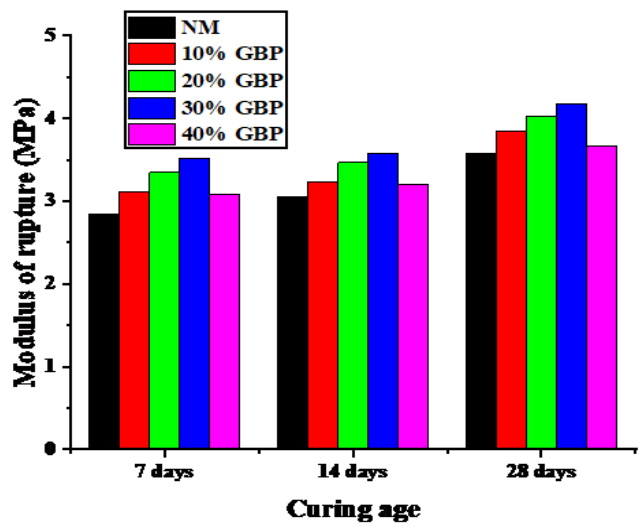

Figure 10. Graphical representation of MOR of concrete with $\%$ glass bottle powder

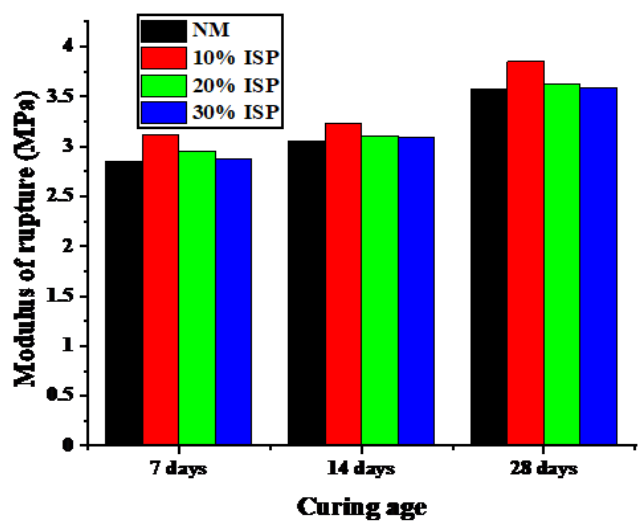

Figure 11. Graphical representation of MOR of concrete with \% illuminate sludge powder

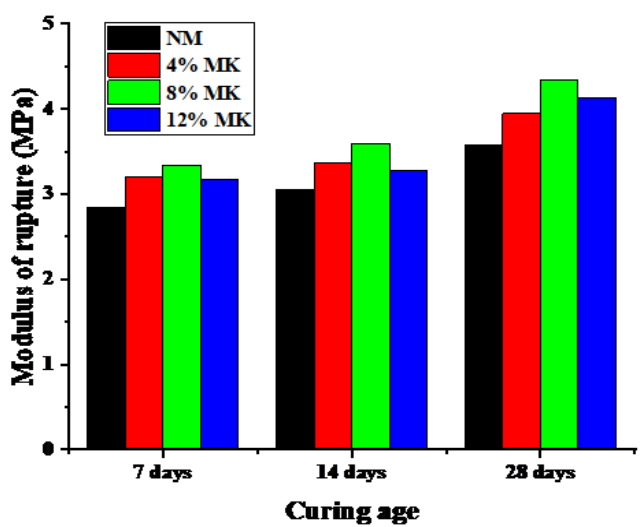

Figure 12. Graphical representation of MOR of concrete with \% metakaolin powder

Modulus of rupture (MOR) of concrete was enhanced with incorporating bottle powder, illuminate sludge and metakaolin up to $30 \%$ replacement to fine aggregate, $10 \%$ replacement with cement, $8 \%$ replacement with cement, respectively. Figure 10, the MOR enhancement with $30 \%$ glass replacement by $20 \%, 22 \%$ and $18 \%$ at 7,14 and 28 days, respectively. The MOR was improved with $10 \%$ replacement illuminate sludge with cement by $8.12 \%, 10.235 \%$ and $7.895 \%$ at 7,14 and 28 days, respectively, as shown in Figure 11. From Figure 12, the MOR enhancement was observed at $8 \%$ replacement of cement with metakaolin by $50.24 \%, 53.21 \%$ and $44.23 \%$ at 7 , 
14 and 28 days, respectively. The MOR enhancement was more with metakaolin in concrete compared to illuminate sludge and glass bottle powder at 7, 14 and 28 days for M30 grade of concrete. The MOR of concrete was increased by filling of micro-pores with metakaolin, glass bottle powder and illuminate sludge powder at an early and later age [18-20].

\section{CONCLUSIONS}

From this research, it is concluded that the maximum compressive strength was observed while incorporating Illuminate sludge and glass bottle in $10 \%$ and $30 \%$, respectively by fine aggregate replacement and metakaolin of $8 \%$ as cement replacement. Maximum tensile strength was achieved by the addition of $20 \%$ glass bottles, and $10 \%$ illuminate sludge by fine aggregate substitutions and metakaolin of $8 \%$ as a cement replacement into the concrete. Maximum modulus of rupture was observed while incorporating Illuminate sludge and glass bottle in $10 \%$ and $30 \%$, respectively by fine aggregate replacement and metakaolin of $8 \%$ as cement replacement. Replacements showed significant enhancement in the concrete due to filling of pores by these waste materials. As a result, incorporating industrial waste will develop high strength concrete as well as being economical and environmentally friendly.

\section{REFERENCES}

[1] Anwar, A. (2016). The influence of waste glass powder as a pozzolanic material in concrete. International Journal of Civil Engineering and Technology (IJCIET), 7(6): 131-148.

[2] Shayan, A. (2002). Value added utilisation of waste glass in concrete. IABSE Symposium Melbourne, pp. 1-11.

[3] Patil, S.N., Gupta, A.K., Deshpande, S.S. (2013). Metakaolin-Pozzolanic material for cement in high strength concrete. IOSR Journal of Mechanical and Civil Engineering (IOSR-JMCE), 46-49.

[4] Srinivasu, K., Krishna Sai, M.L.N., Venkata Sairam Kumar, N. (2014). A review on use of metakaolin in cement mortar and concrete. International Journal of Innovative Research in Science, Engineering and Technology, 3(7): 14697-14701.

[5] Devi, Ch., Saandeepya, M.S., Vimala, R. (2017). Improving the quality of traditional concrete by utilizing flyash and waste glass powder with added substance nylon fiber. International Journal of Civil Engineering and Technology, 8(7): 274-282.

[6] Roy, R., Kumar, P. (2017). Study and experiment analysis of the feasibility of partial replacement of industrial waste glass powder as cement in self compacting concrete. International Journal of Civil Engineering and Technology, 8(6): 1-9. https://doi.org/10.5958/2231-3915.2017.00007.4

[7] Glass Beverage Bottles and Our Environment. https://www.epd.gov.hk/epd/bottles_consult/files/ENG/ Environmental_condoc_ENG_chapter1.pdf, accessed on 19 August 2020.

[8] Pitroda, J., Zala, L.B., Umrigar, F.S. (2013). Innovative use of paper industry waste (Hypo Sludge) in design mix concrete. International Journal of Advanced Engineering and Technology, 3: 31-35.
[9] Jahagirdar, S., Surathkal, S., Manu, B. (2012). Reuse of textile mill sludge in Cement based solid blocks. International Journal of Engineering Research \& Industrial Applications (IJERIA), 5(III): 13-224.

[10] Dinakar, P., Sahoo, P.K., Sriram, G. (2013). Effect of metakaolin content on the properties of high strength concrete. International Journal of Concrete Structures and Materials (IJCSM), 7(3): 215-223. https://doi.org/10.1007/s40069-013-0045-0

[11] Narmatha, M., Felixkala, T. (2017). Analyse the mechanical properties of Metakaolin using as a replacement of cement in concrete. International Journal of Civil Engineering, 4(1): 25-30. https://doi.org/10.14445/23488352/IJCE-V4I1P103

[12] Balakrishnan, R., Ligoria, S.A. (2015). Utilization of Cupola slag in concrete as fine and coarse aggregate. International Journal of Civil Engineering and Technology (IJCIET), 6(8): 06-14.

[13] BIS: 383-1970. (1971). Specification for Coarse and Fine Aggregates from Natural Sources for Concrete. Bureau of Indian Standards, New Delhi, India.

[14] BIS: 2386-1963. (1963). Methods of Test for Aggregates Concrete-Part I Particle Size and Shape. New Delhi, India.

[15] IS 456-2000. (2000). Code of Practice for Plain and Reinforced Concrete. Bureau of Indian Standards, New Delhi.

[16] IS 10262-2009. (2009). Indian Standard Concrete Mix Proportioning - Guidelines. Bureau of Indian Standards, New Delhi.

[17] IS:516-1959. (1959). Indian Standard methods of tests for strength of Concrete. Bureau of Indian standards, New Delhi.

[18] Vishwash, K., Patel, B.R., Varia, D.J. (2016). Suitability of concrete using cupola slag as replacement of coarse aggregate. International Journal of Scientific \& Engineering Research, 7(2): 1182-1186.

[19] Reddy, P.N., Naqsh, J.A. (2019). Development of high early strength in concrete incorporating alccofine and non-chloride accelerator. SN Applied Sciences, 1(7): 111. https://doi.org/10.1007/s42452-019-0790-z

[20] Reddy, P.N., Naqash, J.A. (2019). Effect of alccofine on strength and durability index properties of green concrete. International Journal of Engineering, Transactions C: Aspects, $\quad 32(6)$ : 813-819. https://doi.org/10.5829/ije.2019.32.06c.03

[21] Reddy, P.N., Naqash, J.A. (2019). Experimental study on TGA, XRD and SEM Analysis of Concrete with Ultrafine Slag. International Journal of Engineering, Transactions B: Applications, 32(5): 679-684. https://doi.org/10.5829/ije.2019.32.05b.09

[22] Reddy, P.N., Naqash, J.A. (2019). Properties of concrete modified with ultra-fine slag. Karbala International Journal of Modern Science, 5(3): 151-157. https://doi.org/10.33640/2405-609X.1141

[23] Reddy, P.N., Naqash, J.A. (2020). Effectiveness of polycarboxylate ether on early strength development of alccofine concrete. Pollack Periodica, 15(1): 79-90. https://doi.org/10.1556/606.2020.15.1.8

[24] Reddy, Narasimha, P., Jindal, B.B., Kavyateja, B.V., Reddy, A.N. (2020). Strength enhancement of concrete incorporating alccofine and SNF based admixture. Advances in Concrete Construction, 9(4): 345-354. https://doi.org/10.12989/acc.2020.9.4.345 
[25] Magrini, A., Lazzari, S., Marenco, L., Guazzi, G. (2017).

A procedure to evaluate the most suitable integrated solutions for increasing energy performance of the building's envelope, avoiding moisture problems. International Journal of Heat and Technology, 35(4): 689-699. https://doi.org/10.18280/ijht.350401
NOMENCLATURE

CS

SPT

MKP

GBP

ISP
Compressive strength

Split tensile strength

Metakaolin powder

glass bottle powder

illuminate sludge powder 